
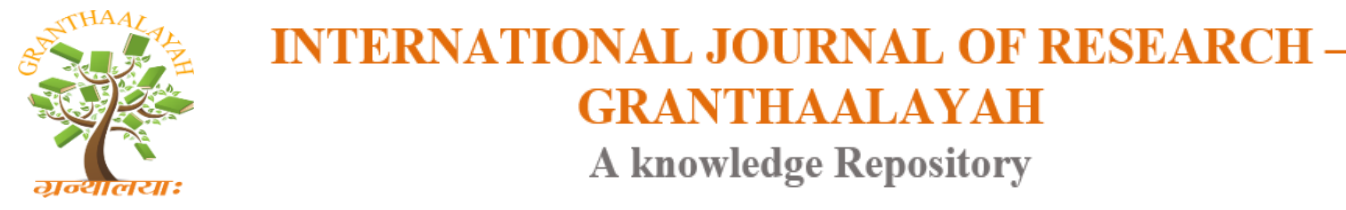

Science

\title{
EVALUATION OF PHYTO-EXTRACTION POTENTIALS AND PERFORMANCE OF FALSE SESAME (CERATOTHECA SESAMOIDES) UNDER INDUCED SOIL POLLUTION BY AUTOMOBILE LUBRICANT IN SAVANNA ECOREGION
}

\author{
Babajide P.A. " ${ }^{*}$, Popoola O.J. ${ }^{2}$, Gbadamosi J. ${ }^{3}$, Oyedele T. A. ${ }^{4}$, Liasu, M.O. ${ }^{5}$ \\ ${ }^{* 1}$ Department of Crop Production and Soil Science, P.M.B. 4000, Ladoke Akintola University of \\ Technology, Ogbomoso, Oyo State, Nigeria \\ ${ }^{2}$ Department of Agricultural Technology, Crop Production unit, Oyo State College of \\ Agriculture and Technology, P.M.B. 10, Igboora \\ ${ }^{3}$ Department of Agricultural Education, Emmanuel Alayande College of Education, PMB 1010, \\ Oyo, Oyo State, Nigeria \\ ${ }^{4}$ Department of Biology, The Polytechnic Ibadan, Ibadan, Nigeria \\ ${ }^{5}$ Department of Pure and Applied Biology, P.M.B. 4000, Ladoke Akintola
}

\begin{abstract}
While strategizing towards achieving improved soil fertility for sustainable tropical crop production, timely application of fertilizers on regular basis alone is not the University of Technology, Ogbomoso, Oyo State, Nigeria best approach, particularly on polluted soils. However, seeking for reliable natural, biological and environment friendly means of ensuring effective riddance of toxic elements or heavy metals from tropical agricultural soils is equally a worthwhile technology. An open-field potted experiment was conducted during early raining season of 2016 (March-July), at the Teaching and Research Farms of Oyo State College of Agriculture and Technology, Igboora, to investigate the effect of spent engine oil polluted soil conditions on performance and heavy metal accumulation potentials of Ceratotheca sesamoides. Spent engine oil was applied at different concentrations $(0.0 \mathrm{ml}, 50.0 \mathrm{ml}, 100.0 \mathrm{ml}, 150.0 \mathrm{ml}$, and $200.0 \mathrm{ml}$ to each pot containing $7 \mathrm{~kg}$ soil. Four pots per treatments were used. The trial was arranged in Completely Randomised Design (CRD), replicated three (3) times. Data were collected on growth parameters (number of leaves, plant height, stem girth, leaf length and leaf breadth). The data were subjected to analysis of variance (ANOVA) and Duncan Multiple Range Test (DMRT) was used to the means. Pre and post-cropping soil analyses were carried out, for determination of nutrient concentrations. Also, after the termination of the experiment, plant samples were collected from each of the pots for oven-drying followed by determination of nutrient concentrations (including the heavy metals). Oil pollution significantly affected growth and heavy metal accumulation of the test-crop. Growth decreases with increasing rate of lubricant application, while the heavy metal concentrations in the test-crop increased with increasing concentrations of the applied spent engine oil. Thus, Ceratotheca sesamoides is a wild plant which could be easily exploited for its heavy metals hyper-accumulative or phyto-
\end{abstract}


extractive potentials, so as to reclaim heavy metals polluted soils from toxicity, for sustainable crop production.

Keywords: False Sesame; Heavy Metals; Soil Pollution; Spent Automobile Lubricant Oil; Hyper-Accumulative Potentials.

Cite This Article: Babajide P.A., Popoola O.J., Gbadamosi J., Oyedele T. A., and Liasu, M.O.. (2017). "EVALUATION OF PHYTO-EXTRACTION POTENTIALS AND PERFORMANCE OF FALSE SESAME (CERATOTHECA SESAMOIDES) UNDER INDUCED SOIL POLLUTION BY AUTOMOBILE LUBRICANT IN SAVANNA ECOREGION.” International Journal of Research - Granthaalayah, 5(11), 355-365,10.29121/granthaalayah.v5.i11.2017.2368.

\section{Introduction}

Undesirable pollution of most tropical agricultural soils by pesticides such as fungicides, bactericides, insecticides, herbicides etc. is not now uncommon. However, incessant and abusive utilization of these chemicals is a major reason for their attributed residual toxic effects on plants, animals and agriculturally beneficial soil microbes in cultivated fields (Sobulo, 2000). Heavy metals are defined as metallic elements that have a relatively high density compared to water (Fergusson, 1990). With the assumption that heaviness and toxicity are inter-related, heavy metals also include metalloids, such as arsenic, that are able to induce toxicity even at low levels of exposure (Duffus, 2002). Amongst such are zinc, copper, cadmium, copper and nickel, which are now imposing serious threats to man, animals and general agricultural activities (Singh et al., 2007). Under normal agricultural circumstances, like other micro nutrients, these mineral elements are needed by plants in traces or small dosages, for proper plant growth and physiological functioning (Hall, 2002). In cases when these nutrients were applied in undesirably high quantities, they become toxic (Kramer et al., 2007). In addition, when these nutrients are available in high concentrations, they were reported to influence general crop performance (Blaylock and Huang, 2000; Hajiboland et al., 2006). The reported sources of heavy metals in the environment include geogenic, industrial, agricultural, pharmaceutical, domestic effluents and atmospheric sources (He et al, 2005; Babajide and Aribisala, 2014). These impose health hazards, as well as reduction in the crop-able hectares of land (Fergusson, 1990; Bradl, 2002; He et al., 2005; Stern, 2010).

However, environmental restoration of polluted soils by conventional technologies demands large economic resources (Cunningham and Berti, 2000; Ensley, 2000; Nascimento and Xing, 2006). Thus, a more affordable approach to de-contaminate soils is increasingly gaining interest nowadays. Phyto-extraction simply means the use of plants to remove heavy metals from soils by storing them in above-ground biomass (Raskin et al., 1997). It has been developed as an economically and environmentally attractive technology to de-contaminate heavy metals polluted soils (Terry and Bañuelos, 2000). So far, two phyto-extraction strategies have been developed. The first one is the use of hyper-accumulating plants which naturally and aggressively consume and concentrate metals in their above ground tissues. The other strategy involves the use of high biomass plants that are induced to accumulate metals through chelants' applications in soils (Blaylock et al., 1997; Huang et al., 1997; Cooper et al., 1999; Melo et al., 2006). The main drawback for the public acceptance of this technique is the risk that synthetic 
chelants pose to environment due to a possible excessive metal solubilization and consequent leaching (Stern, 2010; Chen et al., 2004).

False sesame (Ceratotheca sesamoides) is an annual herbaceous plant belonging to the family Pedaliaceae (Fasakin, 2004). The plant predominantly exists in Africa, Indo-Malayan region and tropical Australia (Fasakin, 2004). It has sixteen (16) genera and sixty (60) species. It possesses tender edible shoots. The leaves and fruits are also eaten whole or in parts either raw or cooked. Sesames were reported to be a good source of protein, oil, vitamins and minerals (Fasakin, 2004; Weiss, 2000; Babajide, 2010). Furthermore, false sesame plant is not recognized as an originally cultivated plant or cultivar, but it is a versatile plant which is highly rated by some local communities for its some reliable medicinal and domestic uses. False sesame is commonly used in the treatments of some deadly childhood diseases such as measles (Fasakin, 2004). The leaves are steeped and the slimy liquid dropped into the eye to treat conjunctivitis, while the mucilage is occasionally used as an emollient and lubricant (Grubben and Denton, 2004). The leaf is a good antioxidant, antiviral, anti-inflammatory and antihypertensive agent. The leaves are used as an abortifacient, as well as for the treatments of cutaneous and subcutaneous parasitic infections, diarrhoea and dysentery, while the seed oil is a useful active insecticide (Fasakin, 2004; Sharma, 2005; El-Habbasa et al., 2007) Although, little is known about its vegetable potentials, the plant grows relatively rapidly and produces considerably high herbage or massive vegetative materials within a short period of time, under favourable edaphic and atmospheric conditions (Fasakin, 2004). However, considering the rapid and aggressive growth attributes, and the early massive formation of foliage, this research work was aimed at harnessing these desirable attributes by evaluating the possible phyto-extractive potentials of false sesame (Ceratotheca sesamoides), under simulated spent engine oil polluted soil.

\section{Materials and Methods}

\subsection{Description of Experimental Location}

The experiment was carried out in the year 2016, at the Teaching and Research farms of the Oyo State College of Agriculture and Technology, Igboora. This experimental site is located on latitude $7^{\circ} 28^{\prime} \mathrm{N}$ and $4^{\circ} 33^{\prime} \mathrm{E}$ in the derived savannah zone of south western Nigeria. Igboora is naturally characterized by bimodal rainfall distribution. The rainfall distribution involves early rains which start in late March / early April and end in late July / early August, followed by a short dry spell in August. The late rainy season spans between August and November.

\subsection{Land Clearing and Pot-Filling}

Land clearing was manually carried out, using hoe and cutlass. After proper manual clearing of the pre-existing vegetation, soil samples were collected at a soil depth of $0-20 \mathrm{~cm}$. The soil samples were carefully packed and mixed together into a composite sample. Samples for soil analyses were collected from this bulk of soil. From the remaining soil sample, each experimental pot was then filled with $7 \mathrm{~kg}$ soil. 


\subsection{Soil Sampling and Analyses}

After land clearing, the pre-planting collection of soil samples was carried out. Soil samples were collected beside the screen house of Agricultural Technology Department, Oyo State College of Agriculture, Igboora. Also, the post-cropping soil sampling was done after the termination of the experiment or harvesting, by placing the soil auger at a depth of 0-20 cm, across the farm plots, After the collection each of the soil samples (pre-cropping and post-cropping) collected were then air dried and sieved, for laboratory analyses of the soil physical and chemical properties. All the unwanted materials such as debris, steel, stone and other foreign particles were carefully removed, from the collected soil samples. The composite auger sample was air dried, crushed and sieved through $2 \mathrm{~mm}$ and $0.5 \mathrm{~mm}$ meshes for the determination of particle size, $\mathrm{pH}\left(\mathrm{H}_{2} \mathrm{O}\right)$, total nitrogen $(\mathrm{N})$, organic carbon, and available phosphorous $(\mathrm{P})$, Iron $(\mathrm{Fe})$, copper $(\mathrm{Cu})$, zinc $(\mathrm{Zn})$, the exchangeable cations ( $\mathrm{Ca}, \mathrm{Na}, \mathrm{Mg}$ and $\mathrm{K})$. The particle size analysis was carried out according to the Bouyoucos (1951) hydrometer method, using sodium hexametaphosphate as the dispersant. The soil textural class was determined from the soil textural triangle. Soil $\mathrm{pH}$ was determined in a 1:1 soil: water ratio and 2:1 soil: $\mathrm{KCl}$ ratio (IITA, 1982). Available phosphorus was determined using Bray and Kurtz P-1 method (Page et al., 1982). Total nitrogen was determined by the micro Kjeldal method (Bremner and Mulvaney, 1989). The exchangeable K and $\mathrm{Na}$ were determined using the EEL flame photometer while $\mathrm{Ca}$ and $\mathrm{Mg}$ were estimated using Versenate titration method, and the organic carbon was determined using the Walkley and Black method (Sumners, 2000).

\subsection{Treatments and Experimental Design}

The spent engine oils were collected from different motor mechanic workshops within Igboora township, in Oyo Sate, Nigeria. The spent engine oils were then carefully and thoroughly mixed together, to ensure homogeneity of the sample. The composite oil sample was then carefully measured into five (5) different volumes or concentrations $(0.0 \mathrm{ml}, 50.0 \mathrm{ml}, 100.0 \mathrm{ml}, 150.0 \mathrm{ml}$, and $200.0 \mathrm{ml}$ ), and applied accordingly to each $7 \mathrm{~kg}$ soil-filled pot. Four pots per treatments were used. The trial was arranged in Completely Randomised Design (CRD), replicated three (3) times. A total number of sixty pots were used for the experiment.

\subsection{Propagation and Agronomic Practices}

The viable false sesame seeds obtained from the seed bank of the faculty of plant and environmental sciences, Oyo State College of Agriculture and Technology, Igboora were sown the nursery. The seedlings were nurtured in the nursery for four weeks, before they were transplanted respectively into the simulated spent engine oil-polluted soils (accept the control, which received no application). It is important to indicate that, prior to the transplanting of false sesame seedlings, the potted contaminated soils at different concentrations were earlier left for two weeks. Transplanting was done at one seedling per hole. This experiment was an open field, and purely a rain-fed involving no artificial watering throughout. Manual weeding was done using hoes around the pots, while hand pulling of weeds inside the pots was carefully done. The weeded plants per pot were returned back into the respective pots soil to decay. 


\subsection{Data Collection}

Collection of data on false sesame growth parameters commenced at eight (8) week after transplanting (8 WAT). The data was collected on: plant height, stem circumference, and leaf length. Plant height was determined by using measuring tape placed at the base of each plant, and made to run to the tip of plant), number of leaves (by direct counting of the fully opened leaves of false sesame), stem girth (with aid of the venier calipers placed at the $10 \mathrm{~cm}$ height of each plant. This first measured the stem diameter, and the value was later converted to stem girth or circumference by a fomular: $\pi \mathrm{D}$ (i.e. 3.142 was then multiplied by the original diameter (D) value obtained from the venier calipers' reading). Also determined were leaf length and leaf width. The leaf length was measured by directly placing the measuring tape at the base of selected leaf and running it on the surface of the leaf to the leaf apex, while the leaf width was determined by placing the measuring tape horizontally at exactly $2 \mathrm{~cm}$ point from the base of each of the selected leaves. However, at the termination of the experiment, the yield parameters measured were ear fresh weight, cob dry weights, grain dry weight, above ground and below ground biomass dry weights, using $\mathrm{Mp} 600 \mathrm{H}$ electronic weighing balance.

\subsection{Plant Sampling and Analysis}

Immediately after termination of the experiment, the harvested plant samples were first weighed, using an electronic weighing balance of model Citizen $\mathrm{Mp} 600 \mathrm{H}$, to determine the sample dry weights. The samples were later oven dried at $80^{\circ} \mathrm{C}$ for 72 hours to a constant weight, according to the procedures described by IITA (1982) and Babajide et al (2012), followed by the determination of nutrient concentrations and uptakes. Total $\mathrm{N}$ was determined by microKjeldahl method. The $\mathrm{P}$ was determined using vanadomolybdate colorimetry, and $\mathrm{K}$ by flame photometry. The concentration of heavy metals in the different samples of soil and plant were determined using AAS. The heavy metals $(\mathrm{Zn})$, nickel $(\mathrm{Ni})$, lead $(\mathrm{Pb})$ and cadmium $(\mathrm{Cd})$ determined were zinc (Sumners, 2000).

\subsection{Statistical Analysis}

All data collected were subjected to analysis of variance (ANOVA). The means were separated using Duncan's Multiple Range Test (DMRT) at 5\% probability level (SAS, 2016).

\section{Results and Discussion}

\subsection{Soil Physical and Chemical Characteristics}

As indicated in Table1, the results from both the pre-cropping and post-cropping soil physicochemical analyses revealed that the soil sample used was sandy-loam in nature. The soil sample was also slightly acidic with $\mathrm{pH}$ values of 6.7 and 6.4 respectively. Also, it was grossly low in major nutrient concentrations. These results were in line with the earlier researchers (Babajide, 2014 and Babajide et al. 2017), who reported that most soils in the savanna ecoregions of Nigeria are marginal and thereby require regular maintenance or supply of organic soil amendments or fertilizers, so as to effectively enhance soil productivity. Also, the reductions (although some nutrient concentrations increased) observed in the concentrations of most of the 
nutrients at the post-cropping stage, were comparable to those at the pre-cropping stage. (Table 1). These established the possibility of natural phenomenon of nutrient absorption or uptakes by plants. Hence, this was in support of Babajide et al. (2012) and Babajide and Oyeleke (2014), who reported relationship between soil nutrition or nutrients availability and nutrient uptakes or absorption under different cropping systems in the tropics.

Table 1: Results of the Pre and Post-cropping Physico-chemical Analysis of the Soil Sample

\begin{tabular}{lcc}
\hline Soil Properties & $\begin{array}{c}\text { Values } \\
\text { (Pre-cropping) }\end{array}$ & $\begin{array}{c}\text { (Post-cropping) } \\
\mathrm{pH}\left(\mathrm{H}_{2} \mathrm{O}\right)\end{array}$ \\
Total N $\left(\mathrm{gkg}^{-1}\right)$ & 6.71 & 6.40 \\
Organic carbon $\left(\mathrm{gkg}^{-1}\right)$ & 0.72 & 0.22 \\
Available P $\left(\mathrm{mgkg}^{-1}\right)$ & 5.08 & 4.16 \\
Exchangeable K $\left(\mathrm{cmolkg}^{-1}\right)$ & 4.13 & 3.32 \\
$\mathrm{Fe}\left(\mathrm{mg} \mathrm{kg}^{-1}\right)$ & 0.46 & 0.38 \\
$\mathrm{Cu}\left(\mathrm{mg} \mathrm{kg}^{-1}\right)$ & 9.82 & 8.70 \\
$\mathrm{Zn}\left(\mathrm{mg} \mathrm{kg}^{-1}\right)$ & 6.36 & 5.94 \\
Exchangeable Na $\left(\mathrm{cmol} \mathrm{kg}^{-1}\right)$ & 2.23 & 2.10 \\
Exchangeable Ca $\left(\mathrm{cmol} \mathrm{kg}^{-1}\right)$ & 0.32 & 0.26 \\
Exchangeable $\mathrm{Mg}(\mathrm{cmol} \mathrm{kg}$ & 0.21 & 0.16 \\
Sand $(\%)$ & 2.71 & 2.46 \\
Silt $(\%)$ & 78.60 & 80.01 \\
Clay $(\%)$ & 07.40 & 07.21 \\
\hline Textural class & 14.00 & 12.78 \\
\hline
\end{tabular}

\subsection{Effects Of Simulated Heavy Metals' Pollution by Spent Automobile Engine Oil on Growth Parameters of False Sesame (Ceratotheca Sesamoides)}

Application of spent engine oil at different concentrations significantly affected growth and development of false sesame (Table 2). The control which did not receive spent oil application had significantly higher values of all the growth parameters measured, compared to the soil polluted counterparts (Table 2). The false sesame' growth parameters such as plant height, number of leaves and stem girth or circumference had significantly lower values, compared to the control. However, application of spent oil at different concentrations did not have significant effects on leaf width and length (Table 2). Although the control had the highest values of the false sesame leaf length and width, the values were not significantly different from those plants which received spent oil application at different concentrations. All these results were in support of Vojtechova and Leblova, (1991); Hajiboland et al., (2006); Babajide and Aribisala (2014), who reported possible influences of soil pollution and soil availability of heavy metals in high dosages on general crop performance, including seed germination and emergence. 
Table 2: Growth parameters of false sesame (Ceratotheca sesamoides) as affected by spent automobile lubricant' pollution

\begin{tabular}{|c|c|c|c|c|c|}
\hline Treatments & $\begin{array}{ll}\begin{array}{l}\text { Plant } \\
(\mathrm{cm})\end{array} & \text { Height }\end{array}$ & $\begin{array}{l}\text { Number of } \\
\text { Leaves }\end{array}$ & $\begin{array}{l}\text { Stem Girth } \\
(\mathrm{cm})\end{array}$ & $\begin{array}{l}\text { Leaf Length } \\
(\mathrm{cm})\end{array}$ & $\begin{array}{l}\text { Leaf Width } \\
(\mathrm{cm})\end{array}$ \\
\hline $\begin{array}{l}\text { Lubricant } \\
\text { application@ } \\
0.0 \mathrm{ml}\end{array}$ & $26.76 \mathrm{a}$ & $30.40 \mathrm{a}$ & $3.60 \mathrm{a}$ & $5.70 \mathrm{a}$ & $2.9 \mathrm{a}$ \\
\hline $\begin{array}{l}\text { Lubricant } \\
\text { application@ } \\
0.50 \mathrm{ml}\end{array}$ & $17.42 \mathrm{~b}$ & $16.60 \mathrm{~b}$ & $2.22 b$ & $5.60 \mathrm{a}$ & $2.8 \mathrm{a}$ \\
\hline $\begin{array}{l}\text { Lubricant } \\
\text { application } \\
@ 100.0 \mathrm{ml}\end{array}$ & $17.30 \mathrm{~b}$ & $15.80 \mathrm{~b}$ & $1.84 \mathrm{~b}$ & $5.46 \mathrm{a}$ & $3.1 \mathrm{a}$ \\
\hline $\begin{array}{l}\text { Lubricant } \\
\text { application@ } \\
\text { 150.0ml }\end{array}$ & $15.58 b$ & $15.20 \mathrm{~b}$ & $1.72 \mathrm{~b}$ & $4.95 \mathrm{a}$ & $2.9 \mathrm{a}$ \\
\hline $\begin{array}{l}\text { Lubricant } \\
\text { application@ } \\
\text { 200.0ml }\end{array}$ & $13.26 \mathrm{~b}$ & $13.80 \mathrm{~b}$ & $1.65 b$ & $4.90 \mathrm{a}$ & $2.8 \mathrm{a}$ \\
\hline
\end{tabular}

\subsection{Spent Automobile Lubricant' Pollution and Yield Parameters of False Sesame (Ceratotheca Sesamoides)}

Application of spent automobile lubricant significantly affected biomass production of false sesame. The control which received no application of the spent engine oil had the significantly higher biomass (above ground and below ground) values, compared to other treatments tested (Table 3). However, the biomass production reduced with increasing dosage of spent engine oil applied. Hence, the higher the concentration of spent engine oil application the lower the biomass production of false sesame (Table 3). These results were in agreement with Blaylock and Huang (2000); Hajiboland et al. (2006); Sing et al. (2007) and Gardestedt et al. (2009), who established the effects of soil pollution with heavy metals on crop performance, including biomass production of many crop plants.

Table 3: Influence of Spent Automobile Lubricant' Pollution on Yield Parameters of False Sesame (Ceratotheca sesamoides)

\begin{tabular}{|c|c|c|c|}
\hline Treatments & $\begin{array}{l}\text { Below-ground Biomass } \\
\left(\text { gplant }^{-1}\right)\end{array}$ & $\begin{array}{l}\text { Above-ground } \\
\left.\text { (gplant }^{-1}\right)\end{array}$ & Biomass \\
\hline Lubricant application@0.0ml & $7.1 \mathrm{a}$ & $26.7 \mathrm{a}$ & \\
\hline Lubricant application@0.50ml & $4.6 \mathrm{~b}$ & $15.8 \mathrm{~b}$ & \\
\hline Lubricant application@100.0ml & $4.2 \mathrm{~b}$ & $14.1 \mathrm{~b}$ & \\
\hline $\begin{array}{l}\text { Lubricant application } \\
150.0 \mathrm{ml}\end{array}$ & $3.8 \mathrm{~b}$ & $11.2 \mathrm{~b}$ & \\
\hline $\begin{array}{l}\text { Lubricant application } \\
200.0 \mathrm{ml}\end{array}$ & $2.7 \mathrm{~b}$ & $11.0 \mathrm{~b}$ & \\
\hline
\end{tabular}




\subsection{Effect of Spent Automobile Lubricant' Pollution on Heavy Metal Concentrations In False Sesame (Ceratotheca Sesamoides) Grown Soil}

Application of spent automobile lubricant significantly enhanced accumulation of different heavy metals in false sesame (Table 4). It was observed that the control which received no application of any spent oil treatments had the significantly lower values across all the heavy metals measured. For nickel (Ni) and zinc ( $\mathrm{Zn}$ ), spent lubricant application at the highest dosage (200.0ml) had the significantly higher values of these two metals, in the soil. Although, the values obtained were not significantly higher than all other concentrations tested, they were higher than the control (Table 4). Like for the nickel (Ni) and zinc ( $\mathrm{Zn}$ ), other two heavy metals measured $(\mathrm{Pb}$ and $\mathrm{Cd})$ followed similar trend of: the higher the dosages applied to soil, the higher the levels of accumulation of heavy metals found in the soil, while the control was observed to be the least accumulated with heavy metals (Table 4). These results were in agreement with Tejada et al. 2005; Babajide, (2010) and Babajide and Aribisala, (2014), who reported the possibility of residual accumulation of applied agrochemicals or any other soil polluting substances in agricultural soils. Also, this research results corroborated the research findings of Sing et al. (2007); Gardestedt et al. (2009) and Mohammadi et al. (2013), who reported phyto-toxic effects of heavy metals on agricultural soils.

Table 4: Concentrations of heavy metal in false sesame (Ceratotheca sesamoides) grown soil as affected by Spent Automobile Lubricant' Pollution

\begin{tabular}{|c|c|c|c|c|}
\hline Treatments & $\begin{array}{c}\mathrm{Ni} \\
\left(\mathrm{mgkg}^{-1}\right)\end{array}$ & $\begin{array}{c}\mathrm{Pb} \\
\left(\mathrm{mgkg}^{-1}\right)\end{array}$ & $\begin{array}{c}\mathrm{Cd} \\
\left(\mathrm{mgkg}^{-1}\right)\end{array}$ & $\begin{array}{c}\mathrm{Zn} \\
\left(\mathrm{mgkg}^{-1}\right)\end{array}$ \\
\hline $\begin{array}{l}\text { Lubricant application@ } \\
0.0 \mathrm{ml}\end{array}$ & $1.40 \mathrm{c}$ & $5.50 \mathrm{c}$ & $0.60 \mathrm{c}$ & $2.10 b$ \\
\hline $\begin{array}{l}\text { Lubricant application@ } \\
0.50 \mathrm{ml}\end{array}$ & $9.35 \mathrm{ab}$ & $33.25 b$ & $3.12 b$ & $5.4 \mathrm{a}$ \\
\hline $\begin{array}{l}\text { Lubricant application } \\
@ 100.0 \mathrm{ml}\end{array}$ & $11.14 \mathrm{a}$ & $34.73 b$ & $3.96 \mathrm{a}$ & $6.3 \mathrm{a}$ \\
\hline $\begin{array}{l}\text { Lubricant application @ } \\
150.0 \mathrm{ml}\end{array}$ & $16.40 \mathrm{a}$ & $51.85 \mathrm{a}$ & $4.16 a$ & $6.8 \mathrm{a}$ \\
\hline $\begin{array}{l}\text { Lubricant application@ } \\
\text { 200.0ml }\end{array}$ & $17.10 \mathrm{a}$ & $61.03 \mathrm{a}$ & $4.67 a$ & $6.8 \mathrm{a}$ \\
\hline
\end{tabular}

\subsection{Phyto-Extraction Potentials of Heavy Metals by False Sesame (Ceratotheca Sesamoides) as Affected by Spent Automobile Lubricant' Pollution}

False sesame (Ceratotheca sesamoides) responded reasonably to the applied automobile lubricant, irrespective of the dosage involved. Meanwhile, from the results of the plant analysis shown on Table 5, the phyto-extraction potentials of false sesame were significantly influenced by application of spent automobile lubricant at different concentrations. However, considering all the heavy metals analysed in the plant samples, it was observed that the control which received no application of any spent oil treatments generally had the significantly lower values (Table 5). Application of spent lubricant at highest dosage $(200.0 \mathrm{ml})$ had the significantly higher values of all the heavy metals measured in plants, but those values obtained were not significantly different from other lower dosages or treatments, while the control was observed to 
have the least value. This research established false sesame as an aggressive consumer of any available soil nutrients, whether toxic or non toxic. Also, this research corroborated the research findings of Naseer et al. (2001); Sing et al. (2007) and Babajide and Aribisala, (2014), who related toxic soil nutrition via undesirable soil pollution by heavy metals to plant phyto-toxic accumulation in some arable tropical plants.

Table 5: Heavy metal concentrations in False Sesame (Ceratotheca sesamoides) as affected by Spent Automobile Lubricant' Pollution

\begin{tabular}{|c|c|c|c|c|}
\hline Treatments & $\begin{array}{c}\mathrm{Ni} \\
\left(\mathrm{mgkg}^{-1}\right)\end{array}$ & $\begin{array}{c}\mathrm{Pb} \\
\left(\mathrm{mgkg}^{-1}\right)\end{array}$ & $\begin{array}{c}\mathrm{Cd} \\
\left(\mathrm{mgkg}^{-1}\right)\end{array}$ & $\begin{array}{c}\mathrm{Zn} \\
\left(\mathrm{mgkg}^{-1}\right)\end{array}$ \\
\hline $\begin{array}{l}\text { Lubricant application @ } \\
0.0 \mathrm{ml}\end{array}$ & $0.60 \mathrm{~b}$ & $0.80 \mathrm{~b}$ & $0.10 \mathrm{~b}$ & $0.40 \mathrm{~b}$ \\
\hline $\begin{array}{l}\text { Lubricant application @ } \\
0.50 \mathrm{ml}\end{array}$ & $1.26 \mathrm{a}$ & $4.93 a$ & $0.70 \mathrm{a}$ & $8.05 a$ \\
\hline $\begin{array}{l}\text { Lubricant application } \\
@ 100.0 \mathrm{ml}\end{array}$ & $1.49 \mathrm{a}$ & $5.12 \mathrm{a}$ & $0.75 a$ & $8.40 \mathrm{a}$ \\
\hline $\begin{array}{l}\text { Lubricant application@ } \\
\text { 150.0ml }\end{array}$ & $1.53 \mathrm{a}$ & $6.12 \mathrm{a}$ & $0.80 \mathrm{a}$ & $8.61 \mathrm{a}$ \\
\hline $\begin{array}{l}\text { Lubricant application@ } \\
\text { 200.0ml, }\end{array}$ & $1.54 \mathrm{a}$ & $6.17 \mathrm{a}$ & $0.93 a$ & $8.50 \mathrm{a}$ \\
\hline
\end{tabular}

\section{Conclusion}

Spent oil pollution significantly influenced false sesame growth and development, as well as the heavy metal accumulation in plants grown on soil polluted soils. The growth of the test crop significantly decreased with application of lubricant at different concentrations, compared to the control. The research therefore established false sesame as an aggressive soil nutrient elements' consumer, which can absorb any nutrient found in available form in the soil, whether such is phyto-toxic or not. This indicated that false sesame is potentially very hyperactive and sensitive to available nutrients irrespective of their levels of concentration. Thus, false sesame (Ceratotheca sesamoides) which is commonly regarded as a weed or wild plant which thrives well under varying climatic conditions could be easily exploited for its heavy metals hyperaccumulative or phyto-extractive potentials, for reclamation of heavy metals polluted soils from their undesirable toxic conditions. This is an affordable and easily adoptable biological and environment friendly low input technology, for improving soil fertility / health, crop productivity and human welfare.

\section{References}

[1] Babajide P.A. and Aribisala L. A. (2014). Evaluation of phytotoxic effects of varying copper and zinc concentrations on seed germination, early growth and biomass yield of sesame (sesamum indicum linn.) and grain amaranth (Amaranthus cruentus) under different growing media. Standard Research Journal of Toxicology and Environmental Health Sciences http://standresjournals.org/journals/SRJTEHS. Vol. 2 (1): 001- 008.

[2] Babajide P.A., Akanbi, W.B., Olabode, O.S., Olaniyi, J.O., Ajibola, A.T. (2012). Influence of pre-application handling techniques of Tithonia diversifolia Hemsl. A. Gray residues on 
growth, seed yield and oil content of sesame (Sesamum indicum 1.), in south-western Nigeria. Journal.of Animal and Plant Sci. Biosci. 15(2): 2135-2146.

[3] Babajide, P. A. (2010). Response of Sesame (Sesamum indicum Linn.) to Integrated Nutrient Management Approach in an Alfisol, in Oyo State, Nigeria (Ph.D. Thesis), University of Ibadan, Ibadan, Nigeria. 173 pp.

[4] Babajide, P. A., Ajibola, A.T., Oyeleye, A. D., Gbadamosi, T. S. and Olla, N.O. (2017). Growth, herbage yield and nutrient uptakes of indigenous jute mallow (Corchorus olitorius) as influenced by different fertilizer sources under dry season alfisols conditions. International Journal of Natural and Applied Sciences. IRJNAS ISSN; 2349-4077. Vol. 4 (5): 1-12.

[5] Babajide, P.A. (2014). Contributions of bio-organo-chemical nutrient management approach to growth, yield and phytochemical composition of sesame (Sesamum indicum Linn.), under low fertile alfisol conditions. International Journal of Current Microbiology and Applied Sciences. ISSN: 2319-7706. Vol. 3. No.3 (8): 957- 976.

[6] Babajide, P.A. and Oyeleke, O.R. (2014). Evaluation of sesame (Sesamum indicum Linn.) for optimum nitrogen requirement under usual farmers' practice of basal organic manuring in the savanna ecoregion of Nigeria. Journal of Natural Science Research. ISSN online 2224-0921 Vol. 4 (17): 122 - 132.

[7] Blaylock M.J., Huang, J.W. (2000). Phytoextraction of metals, In: I. Raskin and B.D. Ensley (Ed.) Phytoremediation proceedings of the 2000 conference on hazardous waste research 139 of toxic metals: Using plants to clean up the environment, John Wiley and Sons, Inc, Toronto, Canada. Pp. 303.

[8] Bouyoucos, G. J. (1951). A recalibration of the hydrometer method for making mechanical analysis of soils. Agronomy Journal 43: 434-438.

[9] Bradl H. (2002). Heavy Metals in the Environment: Origin, Interaction and Remediation Volume 6. London: Academic Press.

[10] Bremner, J. M. and Mulvaney, C.S. (1989). Total nitrogen in methods of soil Analysis Part 2. American Society of Agronomy, Madison W. Pp. 595-624.

[11] Chen, Y., Li, X.D., Shen, Z.G. (2004). Leaching and uptake of heavy metals by ten different species of plants during an EDTA-assisted phytoextraction process.Chemosphere, v.57, p.187196.

[12] Cooper, E. M., Sims, J. T., Cunningham, S. D., Huang, J. W., Berti, W.R. (1999). Chelateassisted phytoextraction of lead from contaminated soils. Journal of Environmental Quality, Vol. 28: 1709-1719.

[13] Cunningham, S.D.; Berti, W.R. (2000). Phytoextraction and phytoestabilization: technical, economic, and regulatory considerations of soil-lead issue. In: Terry, N.; Bañuelos, G. (Ed.) Phytoremediation of contaminated soil and water. Boca Raton: Lewis. p. 359-376

[14] Duffus J.H. (2002). Heavy metals a meaningless term. Pure Appl. Chem. Vol.74 (5):793-807.

[15] El-Habbasha, S. F., Abd-El-Salam, M. S. and Kabesh, M. O. (2007). Response of two sesame (Sesamum indicum L.) varieties to partial replacement of chemical fertilizers by bio-organic fertilizers. Research Journal of Agriculture and Biological Sciences 3(6): 563-571.

[16] Ensley, B.D. (2000). Rationale for use of phytoremediation. In: Raskin, I.; Ensley, B.D. (Ed.).Phytoremediation of toxic metals - Using plants to clean up the environment. New York: John Wiley \& Sons. p.3-11.

[17] Fasakin, K. (2004): Proximate composition of bungu (Cerototheca sesamoides Endl.) leaves and seeds. BIOKEMISTRI 1612): 88 - 92.

[18] Fergusson J.E., The heavy elements (1990). Chemistry, environmental impact and health effects. Oxford: Pergamon Press.

[19] Gardestedt C., Plea, M., Nilson, G., Jacks, B., and Jacks, G. (2009). Zinc in Soils, Crops and meals in Niger Inland Delta, Mali. Ambio. 38: 334-338.

[20] Grubben, G. J. H. and Denton, O. A. (2004). Plant resources of tropical Africa 2. Vegetable, PROTA Foundation, Wageningen; Backhuys, Leiden; CTA, Wageningen, 4:103-111. 
[21] Hajiboland, R., Niknam, V., Ebrahim-Zadeh, H., Mozafari, A. (2006). Uptake, transport and chelation of $\mathrm{Cu}$ and $\mathrm{Zn}$ at toxic levels in tolerant and sensitive species from North West of Iran. J. Sci. 17: $203-214$.

[22] Hall J. L. (2002). Cellular mechanisms for heavy metal detoxification and tofflerance. J. Exp. Bot. 53: 11.

[23] He Z.L., Yang, X.E., Stoffella, P.J. (2005). Trace elements in agroecosystems and impacts on the environment. Journal of Trace Elem Med Biol.19(2-3):125-140.

[24] Huang, J.W.W.; Chen, J.J.; Berti, W.R.; Cunningham, S.D. (1997). Phytoremediation of lead contaminated soils: role of synthetic chelates in lead phytoextraction. Environmental Science and Technology, v.31, p.800-805.

[25] International Institute of Tropical Agriculture (IITA), (1982). Selected methods of soil and plant analysis. IITA Manual series, No. 7. IITA, Ibadan, Nigeria.

[26] Kramer, U., Talke, I., Hanikenne, M. (2007). Transition metal transport, FEBS Lett. 581: 22632272.

[27] Melo, E.E.C.; Nascimento, C.W.A. and Santos, A.C.Q. (2006). Solubilidade, fracionamento e fitoextração de metais pesados após aplicação de agentes quelantes. Revista Brasileira de Ciência do Solo, v.30, p.1051-1060.

[28] Mohammadi Z., Kalat S.M.N. and Haghaghi, R.S. (2013). Effect of copper sulfate and salt stress on seed germination and proline content of Psyllium (Plantago psyllium). American-Eurasian J. Agric. Environ. Sci. 13 (2): 148-152.

[29] Nascimento, C.W.A. and Xing, B. (2006). Phytoextraction: a review on enhanced metal availability and plant accumulation. Scientia Agricola, v.63, p.299-311, 2006.

[30] Naseer, S., Nisar, A., Ashraf, M. (2001). Effect of salt stress on germination and seedling growth of barley (Hordeum vulgare L.). Pak. J. Biol. Sci. 4(3): 359 - 360.

[31] Page, A.L., Miler, R.H. and Keenery, D.R. (1982).Method of Soil Analysis Part 2, Chemical and Microbial Properties. ASA Madison.

[32] Raskin, I.; Smith, R.D.; Salt, D.E. (1997). Phytoremediation of metals: using plants to remove pollutants from the environment. Current Opinion in Biotechnology, v.8, p.221-226, 1997.

[33] SAS (2016). Sas Institute Inc., Cary Nc., U.S.A. (Software Statistical programme). 2016.

[34] Sharma, P. B. (2005). Fertilizer management in Sesame (Sesamum indicum) based intercropping system in Tawab Commandarea. Journal of Oilseeds Research, 22: 63-65.

[35] Singh, D., Nath, K., Sharma Y.K. (2007). Response of wheat seed germination and seedling growth under copper stress. J. Environ. Biol. 28(2): 409-414.

[36] Sobulo, R.A. (2000). Fertilizer use and soil testing in Nigeria. In: Agronomy in Nigeria 2000 Edition. Pp. 195-201

[37] Stern, B.R. (2010). Essentiality and toxicity in copper health risk assessment: overview, update and regulatory considerations. Toxicol Environ Health A. 2010; 73 (2):114-127.

[38] Sumners, M. E. (2000). "Beneficial use of effluents, wastes, and biosolids," Communications in Soil Science and Plant Analysis, vol. 31, No. 11-14, pp. 1701-1715

[39] Tejada, M., Benitez, C. and Gonzatez, J. L. 2005. Effects of Application of Two Organomineral Ferttilizers on Nutrient Leaching Losses and Wheat Crop. Agron. Journ. 97; 960-967

[40] Terry, N. and Bañuelos, G. (2000). Phytoremediation of contaminated soil and water. Boca Raton: Lewis. p.189-200.

[41] Vojtechova, M. and Leblova, S. (1991). Uptake of lead and cadmium by maize seedlings and the effects of heavy metals on the activity of phosphoenol pyruvate carboxilase isolated from maize. Biol. Plant. 33: 386-394.

[42] Weiss, E. A. 2000. Oil seed crops. Blackwell Science Ltd., p.1-142.

*Corresponding author.

E-mail address: pababajide @ lautech.edu.ng, akinbabajide@ yahoo.com 